\title{
Smad3 is required for dedifferentiation of retinal pigment epithelium following retinal detachment in mice
}

\author{
Shizuya Saika ${ }^{1}$, Satoko Kono-Saika ${ }^{2}$, Takeshi Tanaka ${ }^{1}$, Osamu Yamanaka ${ }^{1}$, \\ Yoshitaka Ohnishi ${ }^{1}$, Misako Sato ${ }^{2}$, Yasuteru Muragaki ${ }^{2}$, Akira Ooshima ${ }^{2}$, Jiyun Yoo ${ }^{3}$, \\ Kathleen C Flanders ${ }^{3, *}$ and Anita B Roberts ${ }^{3}$
}

\begin{abstract}
${ }^{1}$ Department of Ophthalmology and ${ }^{2}$ Department of Pathology, Wakayama Medical University, Kimiidera, Wakayama, Japan and ${ }^{3}$ Laboratory of Cell Regulation and Carcinogenesis, National Cancer Institute, National Institutes of Health, Bethesda, MD, USA
\end{abstract}

\begin{abstract}
Retinal pigment epithelial (RPE) cells dedifferentiate and undergo epithelial-mesenchymal transition (EMT) following retinal detachment, playing a central role in formation of fibrous tissue on the detached retina and vitreous retraction (proliferative vitreoretinopathy (PVR)). We have developed a mouse model of subretinal fibrosis with implications for PVR in which retinal detachment is induced without direct damage to the RPE cells. Transforming growth factor- $\beta$ (TGF- $\beta$ ) has long been implicated both in EMT of RPEs and the development of PVR. Using mice null for Smad3, a key signaling intermediate downstream of TGF- $\beta$ and activin receptors, we show that Smad3 is essential for EMT of RPE cells induced by retinal detachment. De novo accumulation of fibrous tissue derived from multilayered RPE cells was seen following experimental retinal detachment in eyes of wild type, but not Smad3-null mice. Expression of $\alpha$-smooth muscle actin, a hallmark of EMT in this cell type, and extracellular matrix components, lumican and collagen VI, were also not observed in eyes of Smad3-null mice. Our data show that induction of PDGF-BB by Smad3-dependent TGF- $\beta$ signaling is likely an important secondary proliferative component of the disease process. The results suggest that blocking the Smad3 pathway might be beneficial in prevention/treatment of PVR.

Laboratory Investigation (2004) 84, 1245-1258, advance online publication, 26 July 2004; doi:10.1038/labinvest.3700156
\end{abstract}

Keywords: retinal pigment epithelial cell; epithelial-mesenchymal transition; transforming growth factor- $\beta$; Smad; proliferative vitreoretinopathy; mouse

Proliferative vitreoretinopathy (PVR) is one of the major complications of rhegmatogenous retinal detachment surgery and is characterized by the formation of scar-like fibrous tissue containing myofibroblasts derived from transdifferentiated retinal pigment epithelial (RPE) cells, as well as other cell types, such as glial cells, which have entered the vitreous and proliferated on both the anterior and posterior surfaces of the detached retina. ${ }^{1,2}$ Such fibrocellular tissue may then contract the retina by a cell-mediated process and ultimately reduce the

Correspondence: Dr S Saika, MD, PhD, Department of Ophthalmology, Wakayama Medical University, 811-1 Kimiidera, Wakayama, 641-0012, Japan.

E-mail: shizuya@wakayama-med.ac.jp

${ }^{*}$ Current address: Department of Microbiology, Gyeongsang National University, Jinju 660-701, Korea and Research Institute of Life Science, Gyeongsang National University, Jinju, 660-701, Korea.

Received 29 May 2004; accepted 10 June 2004; published online 26 July 2004 flexibility of the detached retina. ${ }^{3}$ PVR, like many fibrotic responses, can be considered as an excessive wound healing process. It is the leading cause of failure of retinal detachment surgery and usually results in visual loss. RPE cells are activated upon becoming detached from the retina allowing them to disseminate into the subretinal fluid and to enter the vitreous cavity through the retinal tear. In this disease process, RPE cells then transdifferentiate to mesenchymal-like $\alpha$-smooth muscle actin ( $\alpha \mathrm{SMA})$ positive cells, which produce extracellular matrix and contribute to the accumulation of fibrous scar tissue. ${ }^{2,4}$ PVR is the leading cause of failure of retinal detachment surgery and sometimes results in visual loss.

Transdifferentiation (or dedifferentiation) of RPE cells to an $\alpha$ SMA-positive phenotype is considered to be an example of epithelial-mesenchymal transition (EMT), a program of differentiation whereby cells lose their epithelial morphology and expression of epithelial markers such as E-cadherin, and 
assume a more mesenchymal-like morphology accompanied by expression of markers such as $\alpha$ SMA. ${ }^{2,5}$ Although various growth factors, including platelet-derived growth factor (PDGF), hepatocyte growth factor (HGF), connective tissue growth factor (CTGF), transforming growth factor- $\beta$ (TGF- $\beta$ ), and another member of the TGF- $\beta$ superfamily, activin, are all reportedly involved in the pathogenesis of PVR, ${ }^{6-11}$ we have focused on TGF- $\beta$, because of its correlation with disease severity ${ }^{12}$ and its welldescribed effects on EMT of a variety of epithelial cell types. ${ }^{13-16}$ TGF- $\beta 2$ is expressed at much higher levels than the other TGF- $\beta$ isoforms in the vitreous humor $^{12,17}$ and is a likely mediator of EMT in RPE cells in vivo, although the specific signaling pathways involved have not been identified. ${ }^{5,18,19}$ Moreover, PDGF, TGF- $\beta 1$ and CTGF are each known to be targets of TGF- $\beta 2$ signaling, ${ }^{20-23}$ suggesting that TGF$\beta 2$ could orchestrate the secondary effects of these other peptides on EMT and fibrosis in PVR.

Although TGF- $\beta$ signals are mediated through multiple common pathways including mitogenactivated protein (MAP) kinases, Smad proteins are unique transducers of signals from the TGF- $\beta$ family receptor serine-threonine kinases. ${ }^{24-26}$ Receptor-activated Smad proteins, Smad2 and Smad3, are phosphorylated directly by the TGF- $\beta$ type I receptor kinase (T $\beta R I)$, partner with the common mediator, Smad4, and translocate to the nucleus where they play a prominent role in activation of TGF- $\beta$ dependent gene targets. While it has been suggested that pathways other than the Smad pathway mediate effects of TGF- $\beta$ on EMT, ${ }^{13,15,27,28}$ new data demonstrate conclusively that the Smad pathway, together with MAP kinase pathways, is required for EMT of cells by TGF- $\beta .^{29,30}$ Moreover, we have recently used Smad3 null mice ${ }^{31}$ to demonstrate that EMT in lens epithelial cells in response to capsular injury and in renal tubular epithelial cells in response to injury induced by unilateral ureteral obstruction in vivo is dependent on Smad3 signaling. ${ }^{32,33}$ In these studies, we also showed that lens epithelial cells and renal tubular epithelial cells of Smad3-null mice also lack the ability to undergo EMT in vitro. Based on these findings, we hypothesized that a similar mechanism may be responsible for EMT in RPE cells, and that interference with Smad3 signaling would likely prevent RPE cells from forming the fibrous tissue characteristic of PVR in a model of retinal detachment.

To test this hypothesis, we have investigated the role of TGF- $\beta$ and Smad3 signaling in EMT of RPE cells both in vivo and in vitro. We show for the first time that EMT of RPE cells post experimental retinal detachment in vivo is completely blocked in Smad3 $3^{\text {ex8/ex8 }}$ (knockout (KO)) mice, as evidenced by the absence of expression of EMT markers including $\alpha$ SMA and lumican. Most importantly, the subsequent deposition of collagen and formation of fibrous tissue in the subretinal space seen in eyes of $\mathrm{Smad}^{+/+}$(wild-type (WT)) littermates post retinal detachment does not occur in the absence of Smad3. To confirm these results and to test whether TGF- $\beta$ could initiate these same changes in $\mathrm{RPE}$, we show that TGF- $\beta 2$ can induce EMT in primary porcine RPE cells and a human RPE cell line, ARPE-19, ${ }^{34}$ in association with Smad phosphorylation in vitro. We further show that TGF- $\beta$ accelerates migration of ARPE-19 cells in vitro and induces expression of PDGF-BB, which may contribute to the enhanced proliferation of RPE cells and to expression of collagen type $\mathrm{I}$, the major component of ECM of PVR. ${ }^{35}$ Taken together, our results indicate that Smad3 signaling is required for EMT in RPE cells following retinal detachment and that inhibition of the Smad3 pathway might be desirable clinically to prevent PVR.

\section{Materials and methods}

All the experimental procedures were approved by Wakayama Medical University, Wakayama, Japan and by the Animal Care and Use Committee of the National Cancer Institute, National Institutes of Health, Bethesda, MD, and conducted in accordance with the ARVO Statement for the Use of Animals in Ophthalmic and Vision Research.

\section{Retinal Detachment Model in Mouse Eyes}

Adult KO and WT mice (4-6-week-old, $37 \mathrm{KO}$ and 43 WT mice) were anesthetized with an intraperitoneal injection of pentobarbital sodium $(70 \mathrm{mg} / \mathrm{kg})$. Procedures to induce retinal detachment in the right eye were performed under a surgical microscope after topical application of mydriatics and oxybuprocaine eyedrops. A linear incision was made in the cornea, keeping the limbus intact. The crystalline lens was carefully removed by using a forceps and the vitreous humor was excised, following which the peripheral retina was carefully broken mechanically with a gentle touch with a silicone rubber needle (Alcon Terry's needle). After adding $1.0 \%$ sodium hyaluronate to restore the eye shape, the corneal incision was sutured with 10-0 nylon strings at two sites. Ofloxacine ointment was instilled into the eye and the mice were allowed to heal for specific intervals up to 2 months. Our preliminary experiments showed that the retina becomes detached from the underlying pigment epithelium within 1 day of the surgical procedure. The left eye served as the uninjured control. Proliferating cells were labeled by an intraperitoneal injection of bromodeoxyuridine (BrdU) $2 \mathrm{~h}$ prior to killing the mice by $\mathrm{CO}_{2}$ asphyxia and cervical dislocation; each eye was enucleated, fixed in $4 \%$ paraformaldehyde in $0.1 \mathrm{M}$ phosphate buffer and embedded in paraffin. The number of animals examined at each time point was $5 / 5$ (Day 2), 5/5 (Day 5), 7/7 (Week 1), 7/6 (Week 2), 5/4 (Week 3), 5/5 
(Week 4) and 9/5 (Week 8) for WT or KO mice, respectively.

\section{Wounding of the RPE Cell Layer in Organ-Cultured Mouse Globes}

Both eyes were enucleated from WT and KO mice immediately after being killed as described above. Anterior eye segment structures (cornea and lens) and retina were carefully removed from the globe. After the RPE cell layer had been wounded by scraping using a silicone needle, the tissue was cultured in Eagle's medium supplemented with $10 \%$ fetal calf serum in the presence or absence of human recombinant TGF- $\beta 2$ at $10 \mathrm{ng} / \mathrm{ml}$ for 24 or $48 \mathrm{~h}$. The tissue was routinely fixed and embedded in paraffin as previously reported.

\section{Histology and Immunohistochemistry}

Sections $(5 \mu \mathrm{m})$ were deparaffinized and stained with hematoxylin and eosin (HE) alone or with polyclonal antibodies against collagen type VI (1:100 dilution in PBS, Southern Biotechnology, Birmingham, AL, USA), rabbit polyclonal antilumican antibody $(10 \mu \mathrm{g} / \mathrm{ml}),{ }^{36}$ mouse monoclonal anti- $\alpha$ SMA antibody (1:100 dilution in PBS, NeoMarker, Fremont, CA, USA), goat polyclonal antiPDGF-B antibody (1:200 dilution in PBS, Santa Cruz), mouse monoclonal antiproliferating cell nuclear antigen (PCNA) antibody (1:100 dilution in PBS, Santa Cruz) or with nonimmune IgGs (control). After binding of fluorescence isothiocyanate- labeled secondary antibodies (1:100 dilution in PBS, Cappel ICN, Aurora, OH, USA), the specimens were observed under a fluorescence microscope followed by mounting with VectaShield for nuclear DAPI staining. For quantitation of PCNA- positive cells in vivo, cells counts were restricted a single section $(\times 40)$ of the posterior zone of the eye centered around the optic nerve head and representing approximately $90^{\circ}$ of the circumference of the eye using computer imaging. For BrdU immunostaining, monoclonal anti-BrdU antibody (1:10 dilution in PBS; Boehringer Mannheim, Germany) was used. Deparaffinized sections were treated with $2 \mathrm{~N} \mathrm{HCl}$ for $60 \mathrm{~min}$ at $37^{\circ} \mathrm{C}$ and then processed for indirect immunostaining for BrdU. The antibody complex was visualized with $3,3^{\prime}$-diaminobenzidine as previously reported. ${ }^{37}$

\section{EMT and Smad Phosphorylation in Primary Cultures of Porcine RPE Cells or ARPE-19 Cells}

Cultures of primary porcine RPE cells were prepared by aspirating RPE layers from a hemisectioned pig eye after removing the retina by using a micropipette, and putting the aspirate in a $30-\mathrm{mm}$ diameter collagen-coated plastic culture dish to allow the epithelial cells to outgrow. After reaching confluence, the cells were trypsinized, suspended in Dulbecco's modified Eagle's essential medium (DMEM) supplemented with $10 \%$ fetal calf serum, and seeded on fibronectin-coated chamber slides (Falcon, Becton Dickinson, Lincoln Park, NJ, USA) in the presence and absence of $10 \mathrm{ng} / \mathrm{ml}$ of porcine TGF- $\beta 2$ (R\&D systems Inc., Minneapolis, MN, USA). At 24-h culture intervals, the cells were fixed and immunostained for $\alpha \mathrm{SMA}$.

The ARPE-19 human RPE cell line (ATCC \#CRL$2302)^{34}$ was also used to assess effects of endogenous TGF- $\beta 2$ on expression of $\alpha \mathrm{SMA}$ and Smad3 activation as previously described. ${ }^{32}$ Effects on migration were evaluated using a model of in vitro closure of a monolayer cell sheet in the presence or absence of TGF- $\beta 2$ as previously reported. ${ }^{38}$

\section{Production of PDGF, TGF- $\beta 1$ and Collagen Type $I$ in ARPE-19 Cells Treated with TGF- $\beta 2$}

Expression of PDGF-BB in ARPE-19 cells was assessed by Western blot of cell lysates using PDGF-B (H-55, Santa Cruz Biotechnology, Inc.). Enzyme-linked immunosorbent assays (ELISAs) for PDGF-BB, PDGF-AB and TGF- $\beta 1$ (R\&D Systems, Inc., Minneapolis, MN, USA) were used to determine the concentration of each peptide in the culture medium. ARPE-19 cells were grown in sixwell plates to near confluence and then cultured in $500 \mu \mathrm{l}$ of serum-free DMEM/F-12 supplemented with antibiotics in the presence or absence of human recombinant TGF- $\beta 2(1.0 \mathrm{ng} / \mathrm{ml}$, R\&D Systems, Inc., Minneapolis, MN, USA) for 48 or $96 \mathrm{~h}$. Nine wells were prepared for each culture condition. Medium was processed for ELISAs for determination of the concentration of PDGF-BB and -AB according to the manufacturers' protocols. Medium (48 h) was also processed for the determination of TGF- $\beta 1$ by an ELISA kit (R \& D Systems, Minneapolis, MN). Type I collagen was quantified in medium and sonicated cell lysates $(48 \mathrm{~h})$ and processed for an ELISA system for type I collagen C-terminal peptide (PIP ELISA kit, Takara, Tokyo, Japan). Confluent cells grown on a chamber slides (Nalge Nunc, Naperville, IL, USA) were immunostained for collagen type I (1:100 dilution in PBS, Southern Biotechnology).

\section{Measurement of Proliferation of ARPE-19 Cells}

Effects of adding TGF- $\beta 2$, PDGF-BB, and/or antiPDGF-B-neutralizing antibody on proliferation of ARPE-19 cells were assessed using the MTT assay (TACS MTT Cell Proliferation Assay Kit, Trevigen, Gaithersburg, MD, USA) according to manufacturer's instruction. ARPE 19 cells suspended in DMEM/F-12 supplemented with $15 \%$ fetal calf serum $\left(2 \times 10^{4} / 100 \mu \mathrm{l} /\right.$ well $)$ were seeded in 96 -well culture plates (eight wells for each condition). After $12 \mathrm{~h}$, cells were changed to $100 \mu \mathrm{l}$ serum-free culture 
medium and cultured for an additional $120 \mathrm{~h}$ supplemented with PDGF-BB $(5.0 \mathrm{ng} / \mathrm{ml})$ or TGF$\beta 2(1.0 \mathrm{ng} / \mathrm{ml})$, with either neutralizing anti-PDGF-B antibody $(20 \mu \mathrm{g} / \mathrm{ml})$ or nonimmune IgG $(20 \mu \mathrm{g} / \mathrm{ml})$ as control. At the end of each culture interval, MTT reagent $(10 \mu \mathrm{l})$ was added to each well and the incubation continued for an additional $5 \mathrm{~h}$ at $37^{\circ} \mathrm{C}$. Optical density at $570 \mathrm{~nm}$ was measured $4 \mathrm{~h}$ after adding the lysis solution contained in the kit.

\section{Results}

\section{Histology of RPE in Smad3-Knockout Mice Following Retinal Detachment In Vivo}

Although several methods to induce retinal detachment in a mouse eye have been described, including transgenic expression of PDGF or $\mathrm{VEGF}^{39,40}$ or injection of substances into the subretinal space ${ }^{41-44}$ or into the vitreous, ${ }^{45}$ none of them is appropriate to study EMT of RPE cells, as discussed in detail later.

To address a possible role for Smad3 in the pathogenic response of RPE cells to retinal detachment, we developed a new mouse model of retinal detachment based on a variation of a previously published model, ${ }^{46}$ and examined responses in both KO mice and WT littermates as controls. ${ }^{31}$ The histology of the uninjured retina and RPE cells in $\mathrm{KO}$ and WT eyes was indistinguishable (data not shown). Removal of the crystalline lens and total vitreous humor, followed by a single gentle touch to the peripheral retina by a silicone rubber needle, successfully induced retinal detachment in each mouse without damaging the underlying RPE layers and choroid plexus (Figure 1a,b). Injured eyes of KO and WT mice continued to exhibit a similar histology for the first 2 days postinjury (not shown), but differences were clearly apparent at times after Day 5. At Weeks 1-8 postretinal detachment, RPE cells in the posterior pole region became multilayered in WT eyes (Figure 1a, c, e, g), and took on a thinner, somewhat elongated morphology, whereas cells in KO eyes retained their monolayer organization (Figure 1b, d, f, h). While multilayered proliferating cells could be observed in the peripheral area of both WT and KO eyes postretinal detachment (not shown), fibrous tissues containing multilatered RPEs were formed only in WT eyes and never in KO eyes throughout the healing period. Although it is likely that multilayered cells with pigmented cytoplasm seen in fibrous tissues represent RPEs that have undergone EMT, this cannot be determined from histological examination of HE-stained sections.

\section{Expression of EMT Markers in Cells Following Retinal Detachment is Dependent on Smad3}

Since the histology was suggestive of perturbed EMT, or fibroblastic dedifferentiation of RPE cells in
KO eyes in response to retinal detachment, we examined whether expression of $\alpha \mathrm{SMA}$, that is considered to be a hallmark of EMT and of acquisition of a myofibroblast phenotype $\mathrm{e}^{5,18,19,47}$ would also be reduced or absent in KO eyes. Regardless of the genotype, no $\alpha$ SMA protein was detected in uninjured RPE cells or in the first few days postretinal detachment (Figure 2a, b). At Weeks 1-3, elongated, pigmented fibroblast-like multilayered cells under the detached retina, likely derived from RPE cells, were labeled by the antiaSMA antibody in WT mice (Figure 4c), whereas monolayer RPE cells of KO mice, as well as monolayer cells in WT mice, were not labeled (Figure 2d). At Weeks 4 and 8, prominent fibrous tissue strongly positive for $\alpha \mathrm{SMA}$ could be seen focally in the posterior region of the pigment epithelial layer in WT mice (Figure 2e), whereas intact RPE cells in the posterior region remained unstained in $\mathrm{KO}$ mice (Figure $2 \mathrm{f}$ ).

We also examined the expression patterns of lumican, considered to be another marker for EMT, ${ }^{48}$ and collagen VI, a component of the pathogenic matrix. ${ }^{49}$ Neither of these markers was detected in RPE cells of uninjured eyes of WT or KO mouse (Figure 3b,c), whereas the basement membrane protein, laminin, was detected in Bruch's membrane and choroidal vessels (Figure 3a), and lumican (Figure 3b), and collagen VI (Figure 3c), stained in the scleral matrix and in Bruch's membrane. Collagen VI was also detected in choridal blood vessels. At 1 week postretinal detachment, lumican and collagen VI were expressed in aSMA-positive, pigment-containing, multilayered fibroblast-like cells in WT eyes (Figure 3e,f), whereas they were not seen in RPEs in KO eyes (not shown). At this time point, immunolocalization of laminin was still restricted to Bruch's membrane in WT eyes (Figure 3d) and in KO eyes (not shown). At Week 8, laminin, lumican and collagen VI were all detected in the fibrous tissue formed under the detached retina in WT eyes (Figure 3g-i), whereas they were not detected in intact RPE cells in $\mathrm{KO}$ mice at this same time point (Figure $3 \mathrm{j}-1$ ).

\section{Injury- or TGF- $\beta 2$-Induced EMT of RPE in Organ-Culture or Cell Culture}

To further confirm the Smad3 dependence of EMT of RPE in response to injury, we employed another model involving organ-cultured posterior segments of mouse eyes scrape-wounded in vitro to mimic exposure to vitreous. Wounded WT pigment epithelium expresses $\alpha \mathrm{SMA}$ faintly at $24 \mathrm{~h}$ (data not shown) and then clearly at $48 \mathrm{~h}$ with (data not shown) or without exogenous TGF- $\beta 2$ (Figure 4aA). In contrast, no $\alpha$ SMA-positive RPEs were detected in the wounded $\mathrm{KO}$ mouse eye in the presence (data not shown) or absence (Figure $4 \mathrm{aB}$ ) of exogenous TGF- $\beta 2$ at the same time point. 
WT
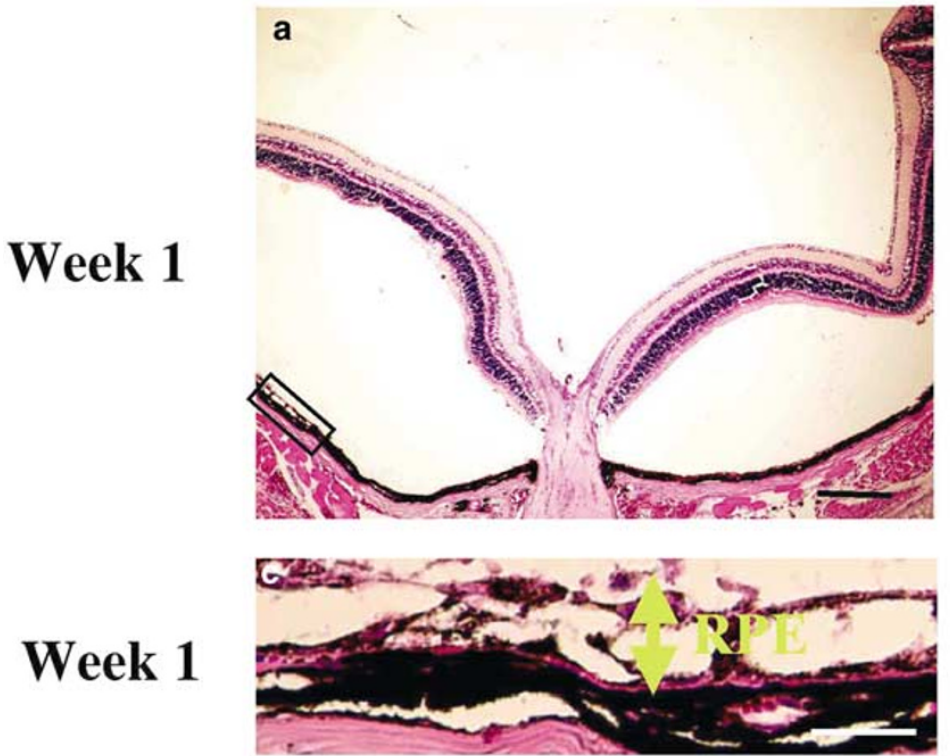

Week 1

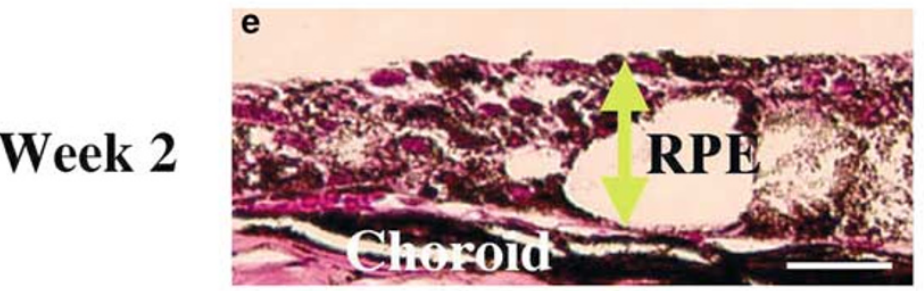

$\overline{9}$

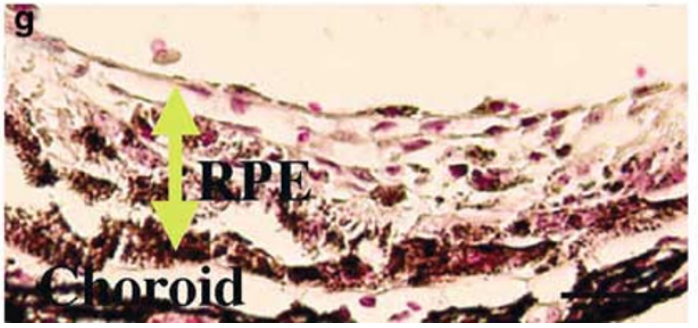

KO
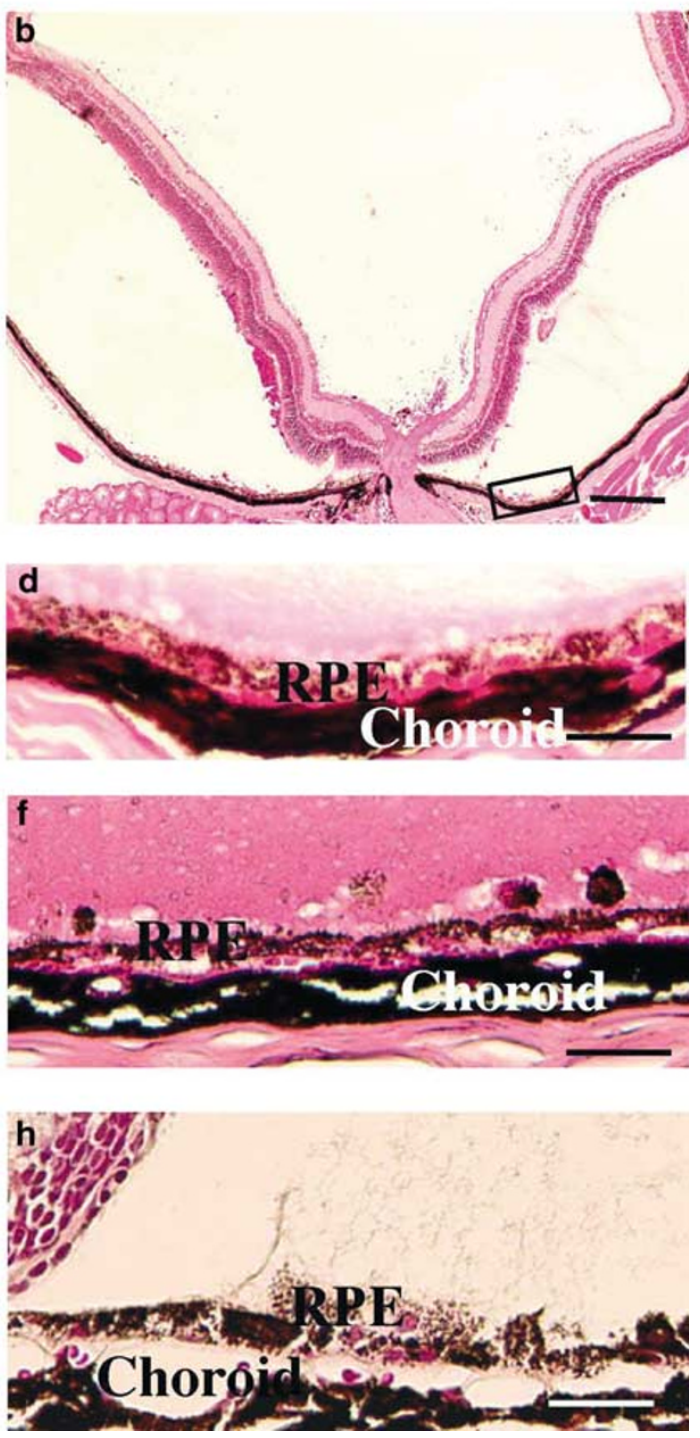

Figure 1 Smad3 is required for transition of RPE cells to a fibroblastic-like morphology following retinal detachment. HE-stained paraffin sections of eyes at Week $1(\mathbf{a}-\mathbf{d}), 2(\mathbf{e}, \mathbf{f})$ and $8(\mathbf{g}, \mathbf{h})$ postretinal detachment. Panels c-f show high-power magnification of the posterior part of the eye. Panels in the left column $(\mathbf{a}, \mathbf{c}, \mathbf{e}, \mathbf{g})$ or those in the right column $(\mathbf{b}, \mathbf{d}, \mathbf{f}, \mathbf{h})$ show histology of Smad3 ${ }^{+/+}(\mathrm{WT})$ or Smad3 $3^{\text {ex8/ex8 }}(\mathrm{KO})$ mouse eyes, respectively. At Weeks 1, 2 and 8, RPE cells in the posterior pole region of WT eyes formed a focal multilayered structure with pigmented cells $(\mathbf{c}, \mathbf{e}, \mathbf{g})$, whereas RPE cells retained their monolayer pattern in KO retinas (d, f, h). Frames $\mathbf{c}$ and $\mathbf{d}$ are high-magnification pictures of the boxed area in frames a and $\mathbf{b}$, respectively. Fibroblast-like RPE cells appeared to be less pigmented at Week 8 as compared with those at Weeks 1 and 2 in WT mice (c, e, g). Bar, $150 \mu \mathrm{m}(\mathbf{a}, \mathbf{b}), 20 \mu \mathrm{m}(\mathbf{c}-\mathbf{h})$.

To examine if this EMT depends on TGF- $\beta 2$, which predominates in the eye aqueous and vitreous, we examined responses of RPE cells to exogenous TGF$\beta 2$ in vitro. Primary porcine RPE cells express $\alpha \mathrm{SMA}$ when cultured in the presence of TGF- $\beta 2$ (Figure $4 \mathrm{bB}$ ), but not in its absence (Figure 4bA), in agreement with that shown previously. ${ }^{5}$ Similar to that shown for primary human RPE cells, ${ }^{19}$ a human RPE cell line, ARPE-19, ${ }^{34}$ also exhibited a morphological change to a more fibroblastic appearance (Figure $4 \mathrm{cB}$ ) and showed clusters of $\alpha \mathrm{SMA}$-positive cells after treatment with TGF- $\beta 2$ for $72 \mathrm{~h}$ (Figure $4 \mathrm{cD}$ ) as compared with cells incubated without TGF- $\beta 2$
(Figure 4cA, C). These data strongly suggest that the aSMA-positive cells in the retinal detachment model in vivo likely arise by EMT of RPEs.

\section{Exogenous TGF- $\beta 2$ or Injury Induces Smad Phosphorylation of RPE Cells In Vitro}

Western blotting showed that Smads2/3 were phosphorylated within $30 \mathrm{~min}$ after exposure to TGF- $\beta 2$ and remained activated throughout the interval examined up to $48 \mathrm{~h}$, although the level of phosphorylation was less than that seen at $30 \mathrm{~min}-1 \mathrm{~h}$ (Figure 5a). To ascertain that the phosphorylated 

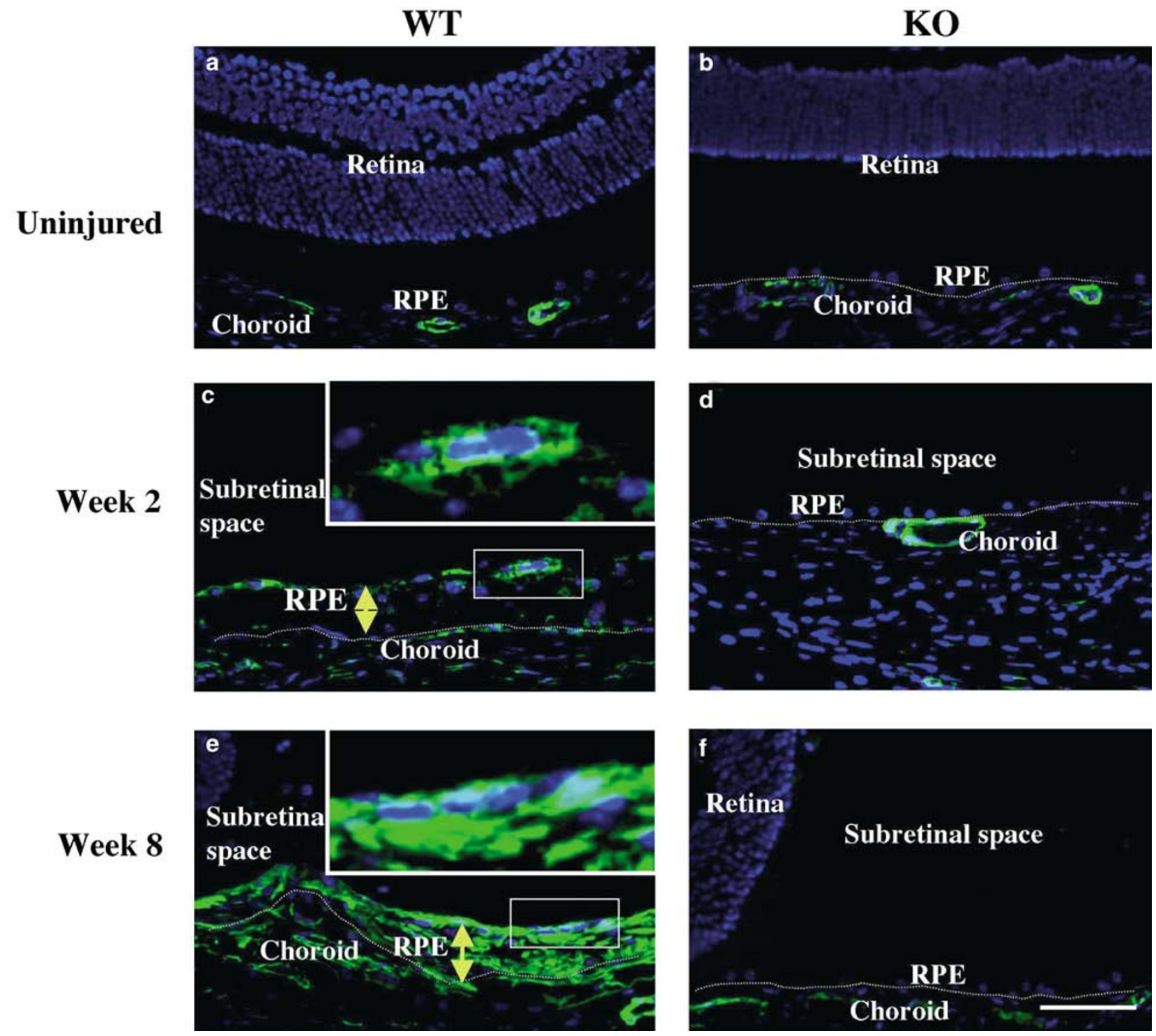

Figure $2 \mathrm{Smad} 3$ is required for expression of $\alpha \mathrm{SMA}$ protein in RPE cells following retinal detachment. Left or right columns represent WT or KO eyes, respectively. Uninjured RPE cells $(\mathbf{a}, \mathbf{b})$ were negative for $\alpha$ SMA protein in both Smad $3^{+1+}(\mathrm{WT})$ and Smad3 $3^{\text {ex8/ex8 }}(\mathrm{KO})$ mice. At 2 weeks postretinal detachment, elongated, multilayered, mesenchymal-like pigmented cells were labeled with anti- $\alpha$ SMA antibody (c) in WT eyes, whereas monolayer RPE cells of KO eyes (d) or WT eyes (not shown) were not labeled. At week 8 (e, f), prominent focal fibrous tissue including pigmented cells of a fibroblastic appearance in WT eyes were markedly positive for $\alpha$ SMA (e), whereas RPE cells in KO mice neither form cell multilayers in the posterior region nor express $\alpha$ SMA in pigment epithelial layer (f). Insets in frames $\mathbf{c}$ and $\mathbf{e}$ show higher magnification pictures of $\alpha \mathrm{SMA}$-expressing cells in the boxed areas. Immunofluorescence staining with DAPI nuclear staining: bar, $50 \mu \mathrm{m}$.

Smad3 translocated to the nucleus, indicative of activation of target gene expression, we analyzed these cells by immunofluorescence. Consistent with the kinetics of Smad phosphorylation, nuclear translocation of Smad3 was at its highest level $1 \mathrm{~h}$ after addition of TGF- $\beta 2$ and was no longer detectable at $24 \mathrm{~h}$ (Figure $5 \mathrm{~b}$ ). These findings suggest that cultured RPE cells can be induced to undergo EMT coincident with activation of the Smad pathway by TGF- $\beta 2$. We then again used immunohistochemistry to examine if Smad3 might also be activated by wounding of RPE monolayer sheet, as might result from autoinduction of TGF- $\beta$ (Figure 5c). Smad3 was detected in the cytoplasm, but not in the nuclei, of ARPE-19 cells immediately after wounding (time 0 ). At $1 \mathrm{~h}$ postwounding, faint immunofluorescence for Smad3 was seen in the nuclei of a few cells (arrowheads), which increased to maximal levels by $7 \mathrm{~h}$ postwounding, a time at which the cells were actively migrating into the wounded space. Similar activation and nuclear translocation of Smad3 has been observed in injured lens epithelial cells. ${ }^{50}$ Addition of exogenous TGF$\beta 2$ accelerated cell migration, resulting in closure of the defect by $12 \mathrm{~h}$ (Figure $5 \mathrm{dD}$ ), compared to $24 \mathrm{~h}$ for the untreated culture (Figure $5 \mathrm{dE}$ ). 

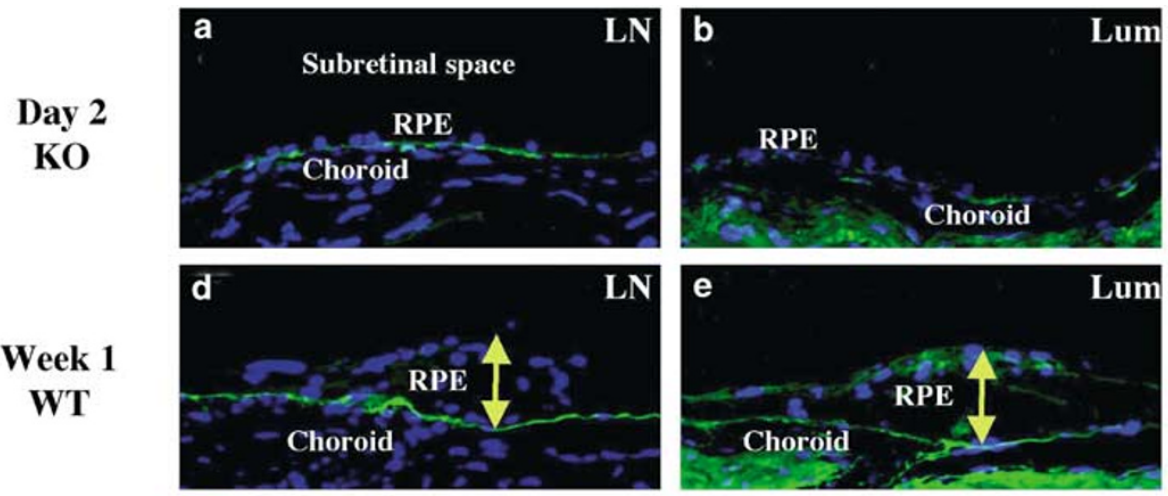

Week 1
WT
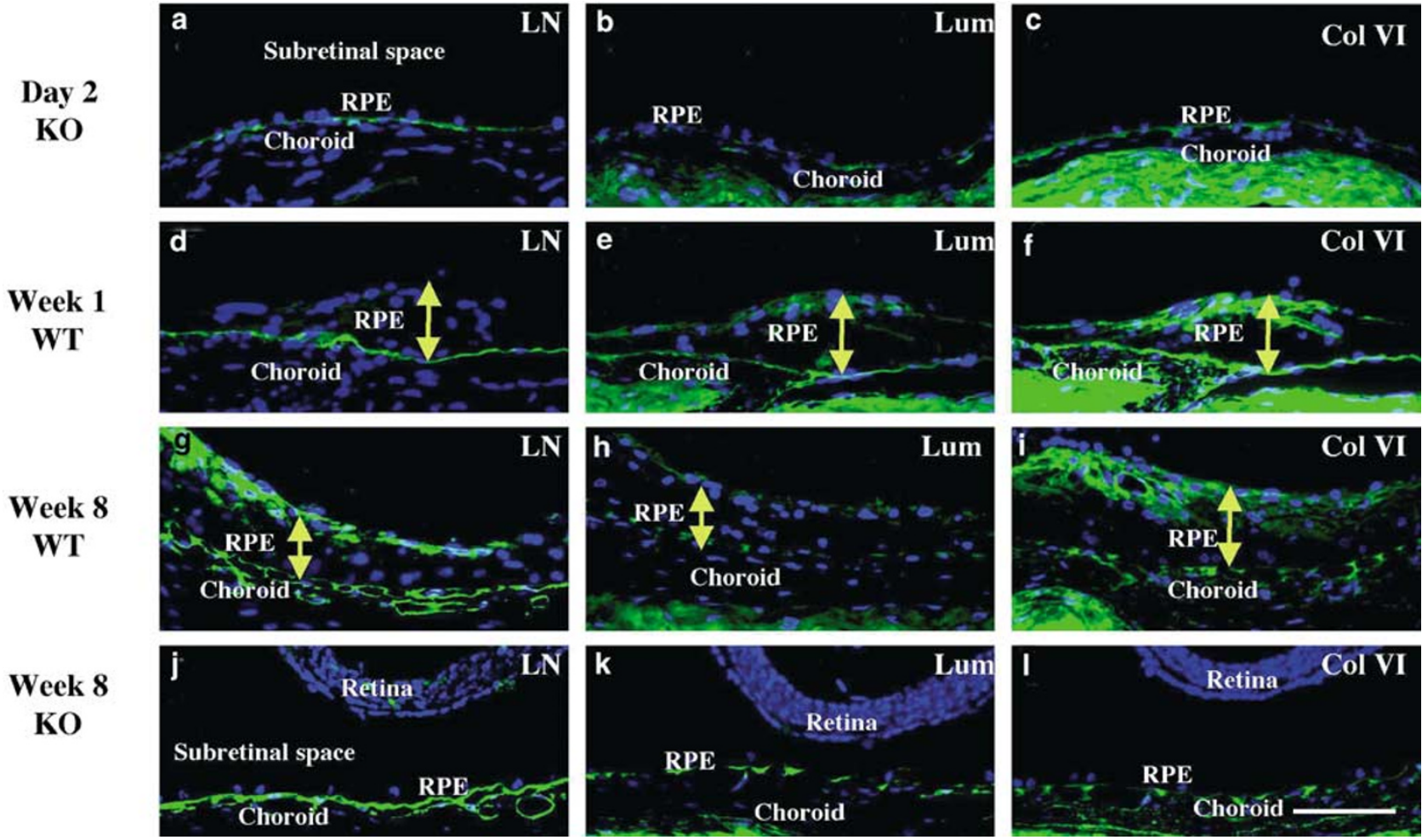

Figure 3 Smad 3 is required for expression of extracellular matrix components laminin, lumican and collagen type VI in subretinal fibrotic tissue formed following retinal detachment. Immunofluorescence staining for laminin (LN, a, d, g, j), lumican (Lum, b, e, h, k) and collagen type VI (Col VI, c, f, i, l) in RPE cells in the posterior region following retinal detachment. Panels a-c and $\mathbf{j}-\mathbf{l}$ represent Smad3 ${ }^{\text {ex8/ex8 }}$ (KO) eyes and those of $\mathbf{d}-\mathbf{i}$ Smad3 ${ }^{+/+}$(WT) mice. Laminin, collagen VI and lumican were not detected in RPE cells of an uninjured eye of WT (not illustrated) or KO mouse (a-c), although weak staining for laminin was detected in Bruch's membrane and choroidal vessels (a), and lumican (b), and collagen VI (c), were observed in scleral matrix. At Week 1 postretinal detachment, lumican and collagen VI were expressed in $\alpha$ SMA-positive (not shown) multilayered fibroblast-like RPE cells in WT eyes (d-f), but not in KO RPE cells (not shown). Laminin immunolocalization is restricted to Bruch's membrane in a WT eye (d). At Week 8, laminin, lumican and collagen VI each stained positively in the fibrous tissue formed under the detached retina in WT eyes (g-i), whereas they were not expressed in RPE cells in KO mice at these same time points (j-l). Immunofluorescence staining with DAPI nuclear staining: bar, $100 \mu$ m.

\section{Proliferating RPE Cells Express PDGF-BB in PVR Tissue Postretinal Detachment In Vivo}

Histologically, RPE cells undergoing EMT in vivo in response to retinal detachment had a multilayered appearance suggestive of proliferation, despite the fact that TGF- $\beta 2$, thought to be a key player in the pathogenesis of PVR, is known to inhibit the proliferation of RPE cells. ${ }^{5}$ To identify and quantify proliferating cells in the RPE multilayer formed under the detached retina, tissues were immunostained with anti-PCNA antibody (Figure 6a) or with anti-BrdU antibody (not shown). PCNA-positive RPE cells were observed in cell multilayers formed in WT mice at Week 1 (Figure 6aA), but not at Weeks 2-8 (not shown). No PCNA-positive cells were detected in the RPE cell layer immediately after induction of retinal detachment in a WT mouse (not shown) or in RPE cells of KO mice at any timepoint (Figure 6aB, at Week 1). These results are quantified in Figure 6b as described in Materials and methods.

Since PDGF-BB, a potent mitogen, has also been implicated in the pathogenesis of PVR both in mice $^{40,41}$ and in humans, ${ }^{6,9}$ we examined if PDGF$\mathrm{BB}$ could be detected in the RPE compartment postretinal detachment. Newly formed PVR tissue in WT mice containing fibroblast-like RPE cells was labeled with anti-PDGF-BB antibody at all times examined after Week 1 postretinal detachment (Figure 6cA), while RPE cells in KO mice neither formed multilayers nor expressed PDGF-BB (Figure $6 \mathrm{cB})$. PDGF was considered to accumulate in matrix of PVR tissue because collagens are known to be ligands for PDGF in tissue. ${ }^{51}$

\section{Effects of TGF- $\beta 2$ and PDGF on Cell Proliferation of ARPE-19 Cells}

Since we showed that PDGF-BB was expressed in PVR tissue of WT mouse eyes in areas of cellular proliferation, but to a significantly lesser extent in RPE in KO eyes following retinal detachment, we examined if exogenous TGF- $\beta 2$ also upregulates PDGF expression in ARPE-19 cells. Western blotting showed a time-dependent upregulation of PDGF-B protein expression beginning about $48-72 \mathrm{~h}$ after addition of TGF- $\beta 2$ (Figure $7 \mathrm{a}$ ). This was confirmed by quantifying PDGF-BB and PDGF-AB in media of confluent cultures by an ELISA. Treatment of cells 


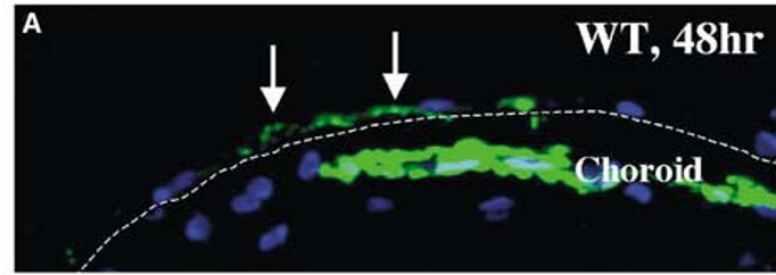

B

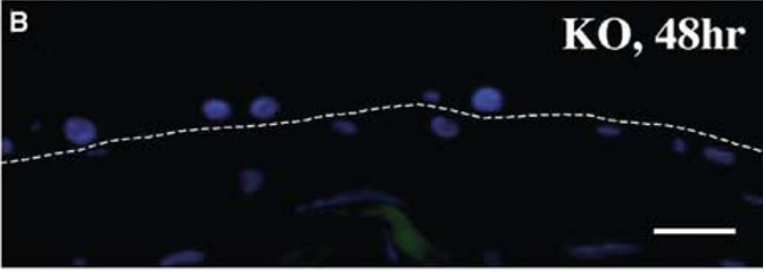

b

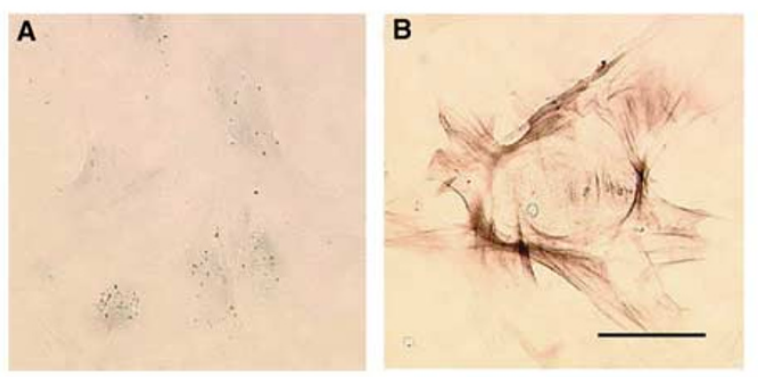

Porcine RPE, $48 \mathrm{hr}$

C

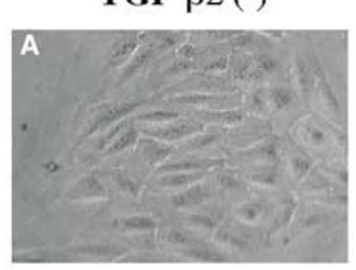

TGF- $\beta$ 2(+)
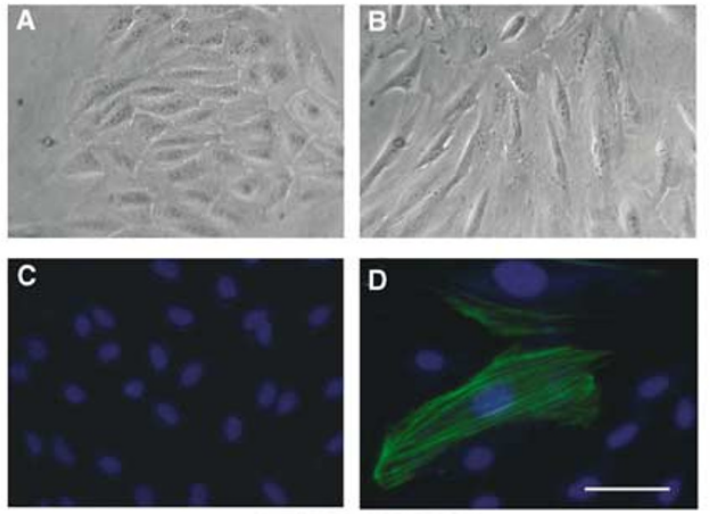

ARPE-19, 72 hr

Figure 4 EMT of RPE cells in organ-culture or cell culture. (a) After $48 \mathrm{~h}$ in organ-culture, injured RPE cells on the Bruch's membrane (white dotted lines) in a $\operatorname{Smad}^{+1+}(\mathrm{A}, \mathrm{WT})$ posterior segment, but not in Smad3 $3^{\text {ex8/ex8 }}$ (B, KO) posterior eye segments, stain positively for $\alpha$ SMA (arrows). WT-injured RPEs in posterior segments cultured express $\alpha$ SMA (A), while KO cells do not. (b) Primary porcine RPE cells cultured on fibronectin do not express $\alpha$ SMA (A) but, undergo EMT, as evidenced by $\alpha$ SMA expression, following exposure to TGF- $\beta 2$ for $48 \mathrm{~h}$ (B). (c) ARPE-19 cells also express $\alpha$ SMA in response to TGF- $\beta$ addition at $72 \mathrm{~h}$ (c) similarly to primary porcine RPE cells. Immunofluorescence staining with DAPI nuclear staining $(\mathrm{A}, \mathrm{C})$; indirect immunostaining by diaminobenzidine color reaction methylgreen counterstaining (B); bar, $10 \mu \mathrm{m}$ (A), $100 \mu \mathrm{m}$ (B), $50 \mu \mathrm{m}$ (C).

with TGF- $\beta 2$ increased the amounts of PDGF-BB protein secreted into the culture medium over twofold above that of control cultures (Figure 7b). The concentration of PDGF-BB reached approximately $500 \mathrm{pg} / \mathrm{ml}$ in cultures treated with TGF- $\beta 2$ for $96 \mathrm{~h}$. Although the total amount of PDGF-AB secreted by ARPE-19 cells was much less as compared to that of PDGF-BB, its production was also significantly increased in the presence of TGF- $\beta 2$. The crystal violet color reaction was used to show that there were no significant differences in the cell numbers among these cultures (data not shown).

Since RPE cells proliferate to form subretinal PVR-like tissue postretinal detachment in vivo, and since TGF- $\beta 2$ inhibits the growth of most epithelial cells, we examined effects of TGF- $\beta 2(1 \mathrm{ng} / \mathrm{ml})$, PDGF-BB ( $5 \mathrm{ng} / \mathrm{ml}$ ), and TGF- $\beta 2$ plus anti-PDGF-B antibody $(20 \mu \mathrm{g} / \mathrm{ml})$ on cell proliferation in sparse, growing, cultures of ARPE-19 cells (Figure 7c). The efficacy of the anti-PDGF-B antibody was confirmed in cultures containing both PDGF-BB and the neutralizing antibody in a $120 \mathrm{~h}$ culture. As expected, PDGF-BB enhanced and TGF- $\beta 2$ inhibited the growth of the cells in a time-dependent manner as measured by the MTT assay. Addition of a PDGFB neutralizing antibody to TGF- $\beta 2$ culture resulted in further suppression of cell proliferation, suggesting that the time-dependent accumulation of endogenous PDGF-BB might counteract the growth inhibitory effects of exogenous TGF- $\beta 2$.

\section{ARPE-19 Cells Express TGF- $\beta 1$ and Collagen Type I When Treated with TGF- $\beta 2$}

Treatment of ARPE-19 cells for $48 \mathrm{~h}$ with exogenous TGF- $\beta 2$ caused a significant increase in expression of TGF- $\beta 1$ (Figure 8a). TGF- $\beta$-treated cells also show increased deposition of type I collagen as shown by both immunofluorescence and by quantifying in culture medium and cell lysate using an ELISA assay (Figure 8b,c), suggesting that the Smad3dependent deposition of collagen in the subretinal space postretinal detachment in vivo is likely also dependent on TGF- $\beta 2$. It is still unclear whether the type I isoform of TGF- $\beta$ is also important in PVR since we did not observe significant immunostaining for TGF- $\beta 1$ in cell multilayers formed beneath the detached retina in WT mice (data not shown).

\section{Discussion}

In the present study, we have shown that dedifferentiation or EMT of RPE cells to a myofibroblast phenotype following retinal detachment is dependent on the presence of Smad3, a key cytoplasmic signal transducing element downstream of TGF- $\beta$ superfamily receptors. Our data thereby strongly implicate activation of this particular pathway by TGF- $\beta 2$, or possibly another member of the TGF- $\beta$ superfamily, activin, which shares this same downstream mediator, in the pathogenesis of PVR (Figure 9). The exposure of WT RPE cells to subretinal fluid in a model of retinal detachment 
a

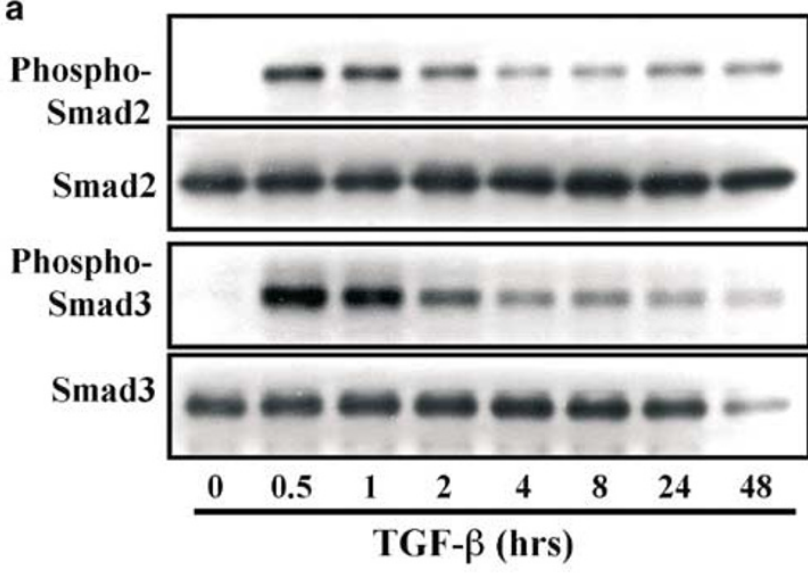

b
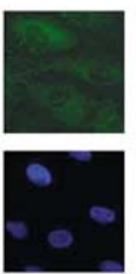

0
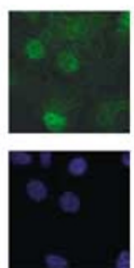

0.5

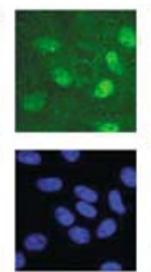

1

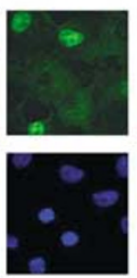

6

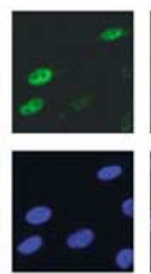

12

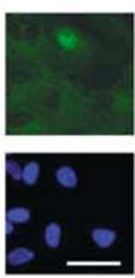

24

TGF- $\beta 2$ (hrs)

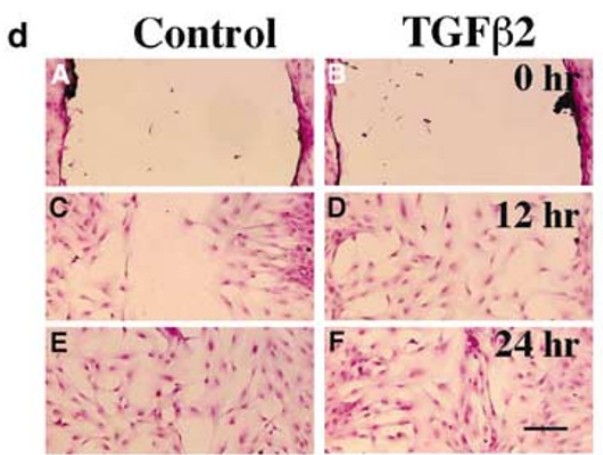

Figure 5 TGF- $\beta 2$ or injury induces Smad phosphorylation of ARPE-19 cells and TGF- $\beta 2$ enhances cell migration in vitro. In ARPE-19 cells Smads $2 / 3$ are phosphorylated within 30 min after TGF- $\beta 2$ addition (a) and nuclear translocation of Smad3 is also observed within $0.5 \mathrm{~h}$ with maximal levels $1 \mathrm{~h}$ after TGF- $\beta 2$ addition (b). (c) Following wounding of a monolayer of ARPE-19 cells, nuclear translocation of Smad3 was observed in cells near the wounded edge beginning $1 \mathrm{~h}$ after injury and increasing to maximal level $3-7 \mathrm{~h}$ postwounding. Arrowheads or arrows indicate weak or obvious staining for nuclear Smad3 in ARPE-19 cells, respectively. Nuclear Smad3 is no longer detected at $24 \mathrm{~h}$ postwounding. (d) Migration of ARPE-19 cells is accelerated by adding TGF- $\beta 2$ ( $1.0 \mathrm{ng} / \mathrm{ml})$ to the culture medium. The cleared defect in wounded ARPE-19 monolayers is filled within $12 \mathrm{~h}$ in cultures treated with TGF- $\beta 2$, compared to $24 \mathrm{~h}$ in untreated control cultures. Immunofluorescence staining with DAPI nuclear staining (B, C) and HE staining (D); bar, $50 \mu \mathrm{m}$ (B, C), $200 \mu \mathrm{m}$ (D).

induced de novo expression of $\alpha \mathrm{SMA}$ and other markers, including matrix components, leading ultimately to fibrosis, and thus modeling the key features of the human disease PVR. ${ }^{2}$ This is consistent with our earlier report showing a correlation between levels of TGF- $\beta 2$ in the vitreous and the degree of severity of PVR, ${ }^{12}$ and with identification of activin both in PVR and as a product of RPE cells in vitro. ${ }^{10,52}$

To address the mechanisms contributing to dedifferentiation of resident RPE cells induced by retinal detachment, we developed a new model of retinal detachment in the mouse eye which results in separation of the neural retina from the underlying pigment epithelium without mechanical damage to the pigment epithelial layer. Although several models for retinal detachment have been used to identify pathogenic mechanisms that contribute to PVR, none of them were suitable for our purpose. For example, a commonly used model that has demonstrated roles for PDGF and the PDGFR $\alpha$ involves an injection of genetically engineered or normal conjunctival fibroblasts into the vitreous. ${ }^{41-43}$ This model is based on study of effects of gene products of ectopic mesenchymal cells, presumably modeling fibroblast-like cells that might arise from dedifferentiation of RPE cells in the response to injury. As a result of this, it cannot be used to study the earlier stages of PVR dependent on dedifferentiation of resident RPE cells. Other models of PVR are based on transgenic mice in which overexpression of various growth factors in the photoreceptor cells leads to traction detachment of the retina. ${ }^{39,40}$ Again, these approaches are not suitable because forced alteration of the cytokine expression profile likely changes the response of RPE cells postretinal detachment. Similarly, induction of PVR by an intravitreal injection of dispase is likely to stimulate retinal glial cells to migrate toward the subretinal space, ${ }^{45}$ thereby complicating analysis of the cellular origin of the fibrous tissue. So while each of these models provides insights into specific aspects of PVR, most of them represent an unlikely extreme that neither mimics the natural pattern of cytokine expression nor models the cellular origin of the fibrous tissue during the pathogenesis of PVR. The model we have used here has been modified from one originally described elsewhere. ${ }^{46} \mathrm{~A}$ disadvantage of our model (Figure 9) is that the RPE cells are confined to the subretinal space and do not migrate into the vitreous as in PVR. However, this model does support analysis of both the initial events 
involved in activation and dedifferentiation of RPE cells to a mesenchymal phenotype and later events that lead to accumulation of ECM.

a

WT

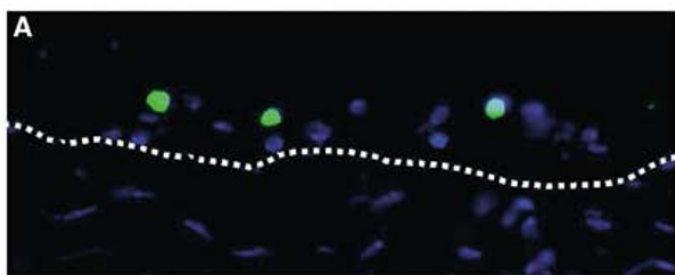

KO

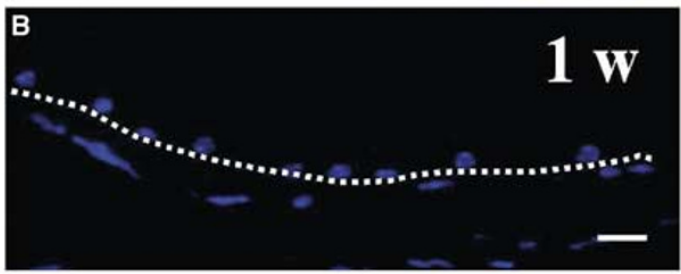

b

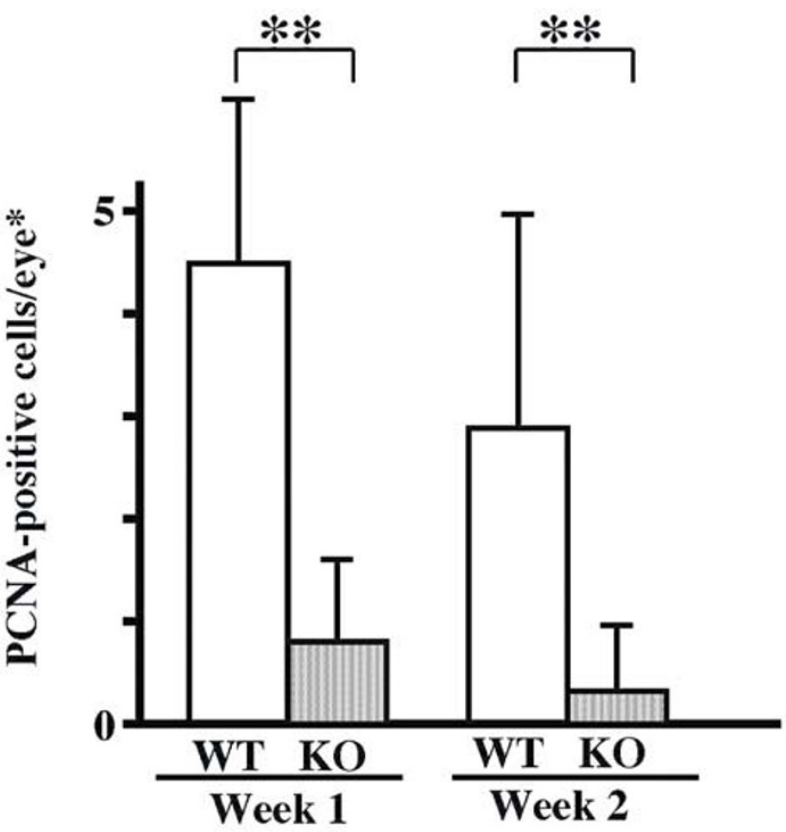

C

WT

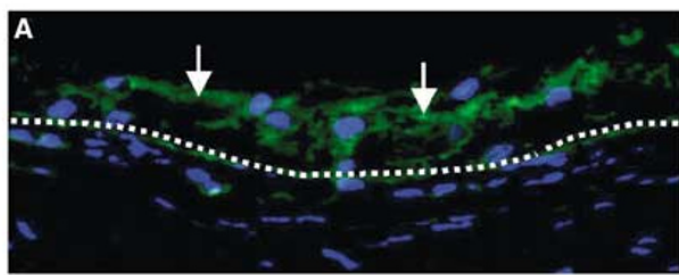

KO

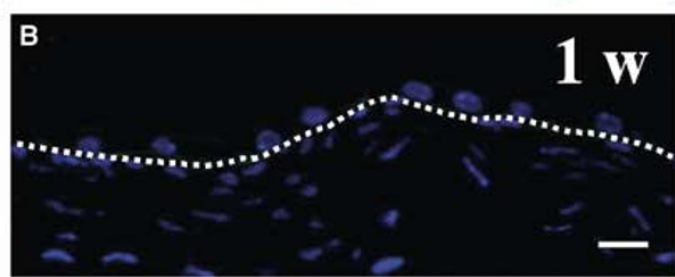

Using this model, we have shown that WT RPE cells appear to undergo a morphological transdifferentiation to fibroblast-like cells, while retaining expression of pigment in the cytoplasm following retinal detachment in vivo. These histological findings prompted us to hypothesize that these RPE cells are undergoing EMT. Indeed, the cells display all of the classic features of EMT including expression of $\alpha \mathrm{SMA}$, the hallmark of myofibroblasts, and lumican and collagen VI, components of the pathologic ECM. ${ }^{49}$ None of these markers is detectable in RPE cells in eyes of Smad3 null mice postdetachment. Our in vivo results are supported by organ culture of injured WT and KO murine pigment epithelium in vitro and by data obtained with both primary porcine RPE cells and with a human RPE cell line, ARPE-19, ${ }^{34}$ where treatment with TGF- $\beta 2$ activated Smad signaling and induced expression of aSMA and collagen. Others have used electronimmunocytochemical techniques to conclude that fibroblast/fusiform-shaped cells seen in epiretinal membranes from PVR and in cultured human RPE cells treated with pathologic vitreous from PVR arise by dedifferentiation of RPE cells by the process of EMT. $^{2}$ Together these studies show that the mouse model induces similar transdifferentiation of RPE cells as seen in PVR, and implicates TGF- $\beta 2$ in initiating these changes. Since both our in vivo data and organ-culture experiments showed these changes to be absent in eyes of mice lacking Smad3, these data implicate the Smad3 pathway in injuryinduced transdifferentiation or EMT of RPE cells, and ultimately in processes leading to fibrosis and traction detachment of the retina characteristic of PVR.

Recently, we have shown a similar requirement for Smad3 in injury-induced EMT of both lens epithelial cells and kidney tubular epithelial cells using mouse models of lens anterior capsular opacification and obstructive kidney disease, respectively. ${ }^{32,33}$ In the ocular lens, similar to what we report here in the pigment epithelium, the genera-

Figure 6 Increment of cell proliferation in RPE cells and PDGF-BB expression in Smad $3^{+/+}$(WT), mice, but not seen in Smad3 ${ }^{\text {ex8/ex8 }}(K O)$ mice, postretinal detachment. PCNA-positive RPEs were observed in cell multilayers formed in WT mice at Week 1 (aA) and 2 (not illustrated), but not at Week 4 and 8 (not illustrated). No PCNA-positive cells were detected in RPE cells immediately after retinal detachment induction in a WT mouse (not illustrated) or in RPE cells of KO mouse at any timepoint ( $\mathbf{a B}$, at Week 1). Frame b shows the number of PCNA-positive RPE cells in posterior part of the eye at Weeks 1 and 2 following retinal detachment. More PCNA-labeled cells are detected in WT eyes as compared with KO eyes. Newly formed PVR tissue in WT mice containing fibroblast-like RPE cells were labeled with anti-PDGF-BB antibody at all times examined after Week 1 postretinal detachment (cA), while RPE cells in KO mice neither formed a cell multilayer nor expressed PDGF-BB (cB), White dotted lines, Bruch's membrane. Immunofluorescence staining with DAPI nuclear staining (a, c): bar, $10 \mu \mathrm{m}$. 
tion of cells expressing lumican and $\alpha \mathrm{SMA}$ postinjury has a stringent dependence on Smad3. ${ }^{32} \mathrm{In}$ each of these models, in vitro studies with lens epithelial cells and primary kidney tubular epithe-

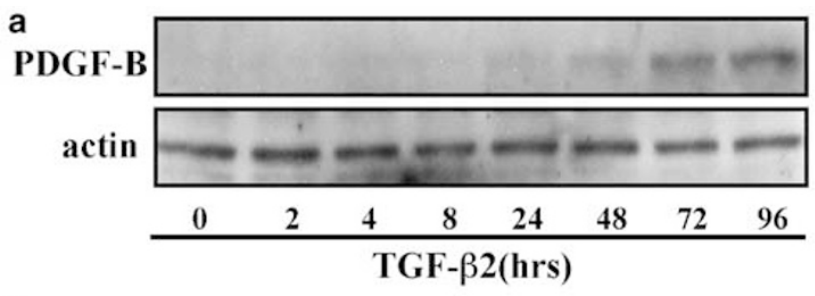

b
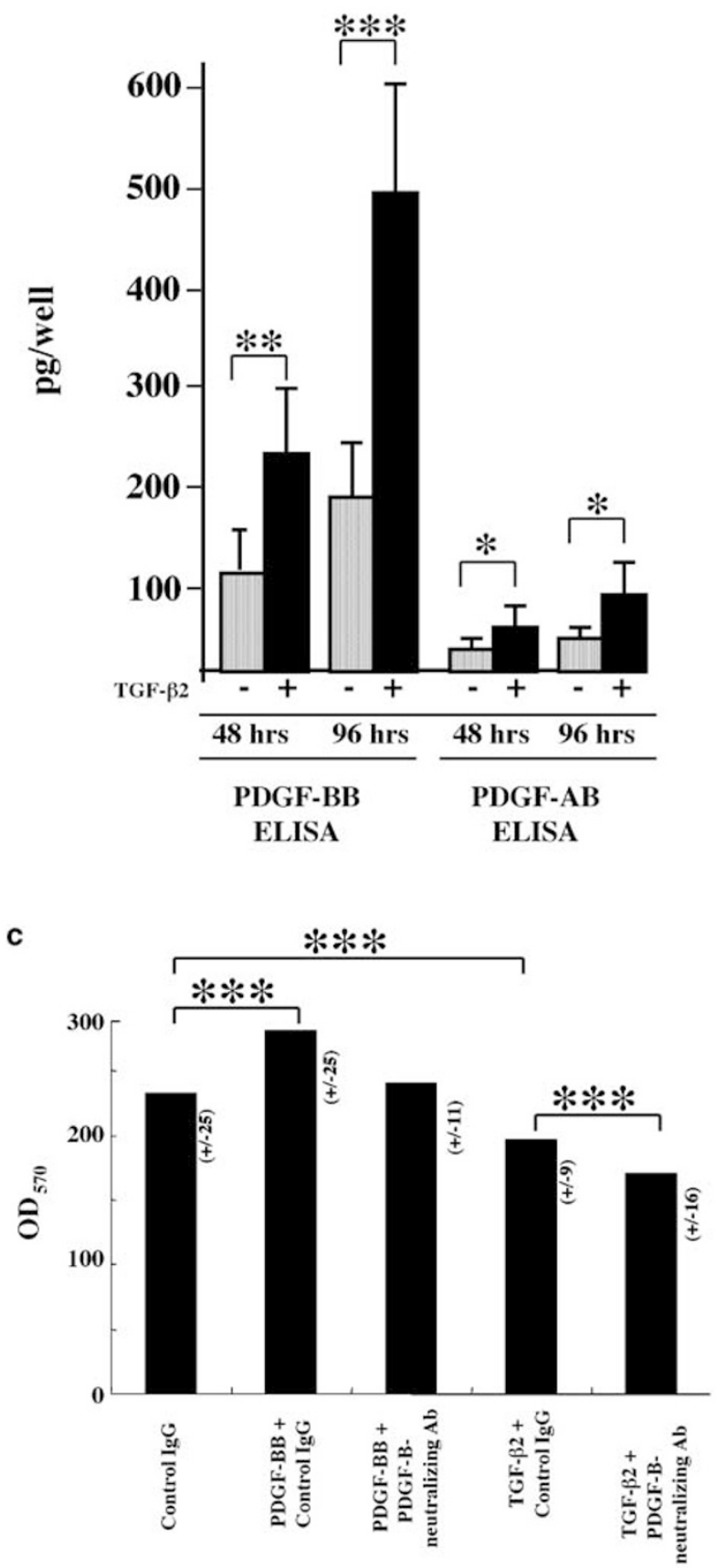

lial cells demonstrated that the effects of injury in vivo are recapitulated by treatment of cells with TGF- $\beta$ in vitro, suggesting that injury induces activation of TGF- $\beta$, which then drives the fibrotic sequelae dependent on signaling through the Smad3 pathway. This implication of the Smad3 pathway as essential for injury-induced EMT is also supported by studies in NMuMg murine mammary epithelial cells, where use of a mutant T $\beta$ RI unable to bind or activate Smad2/3 but still competent to signal through MAPK pathways, has shown that the Smad pathway is necessary but possibly not sufficient to effect EMT driven by TGF- $\beta{ }^{29,30}$ Some of the cooperating pathways are likely to include phosphatidylinositol 3-kinase, RhoA, and MAPK pathways. ${ }^{13,15,27,28}$

While our data clearly implicate TGF- $\beta /$ Smad 3 signaling in EMT of RPE cells in vivo, and likely also in their migration postinjury, thought to contribute to the contractile properties fibrocellular membranes, ${ }^{3}$ cytokines other than TGF- $\beta$ probably contribute to the proliferative aspects of the disease. TGF- $\beta$ is inhibitory to growth of RPE cells ${ }^{5}$ and on epithelia in general. ${ }^{53}$ Many lines of evidence suggest that PDGF, a mitogenic growth factor, might contribute to the proliferation of RPE cells postinjury. PDGF, like TGF- $\beta 2$, has been implicated in PVR in $v i v o^{6,9,40}$ and in accelerating transition of RPE cells in vitro. ${ }^{47}$ Moreover, an in vitro model of the later contractile stages of PVR has shown that PDGF mediates the contractile effects of TGF- $\beta$ on RPE cells. ${ }^{22,54}$ Our studies now show that TGF- $\beta$ can induce synthesis and secretion of PDGF-BB and PDGF-AB in ARPE-19 cells, similar to its ability to induce synthesis of PDGF and activate PDGF receptors in a variety of other cells. ${ }^{20,21,55}$ Importantly, this induction of PDGF by TGF- $\beta$ has recently been demonstrated to be $\operatorname{Smad} 3 / 4$ dependent, ${ }^{56}$ consistent with absence of PDGF-BB expression in the KO RPE cells postretinal detachment. The Smad3 dependence of PDGF-BB expression in vivo further suggests that its expression is dependent on TGF- $\beta$ rather than a direct result of the injury. This is

Figure 7 TGF- $\beta 2$ induces expression of PDGF in ARPE-19 cells that modulates its effects on cell proliferation. (a) Western blot of PDGF-B in ARPE-19 cells treated with $1.0 \mathrm{ng} /$ $\mathrm{ml}$ of TGF- $\beta 2$ for $0-96 \mathrm{~h}$. PDGF-B chain is detected at $24 \mathrm{~h}$ culture increases up to $96 \mathrm{~h}$ after addition of TGF- $\beta 2$. (b) Total amount of PDGF-BB and PDGF-AB in culture medium detected by using an enzyme-immunosorbent assay as described in Materials and methods. TGF- $\beta 2$ stimulates production of PDGF-BB and -AB by the cells. We then examined effects of TGF- $\beta 2$, PDGF-BB and TGF- $\beta 2$ plus anti-PDGF-B antibody on cell proliferation of ARPE-19 cells. PDGF-BB $(5 \mathrm{ng} / \mathrm{ml})$ enhanced and TGF- $\beta 2(1 \mathrm{ng} / \mathrm{ml})$ inhibited the growth of the cells. Addition of a PDGF-B neutralizing antibody $(20 \mu \mathrm{g} / \mathrm{ml})$ to TGF- $\beta 2$ culture resulted in further suppression of cell proliferation at later time points of $120 \mathrm{~h}$ culture, suggesting that the accumulation of endogenous PDGF-BB might counteract the growth inhibitory effects of exogenous TGF- $\beta 2$. 
consistent with the delayed expression of PDGF both in vivo and in vitro and the demonstration that antibodies to PDGF-BB enhanced the growth sup-

a

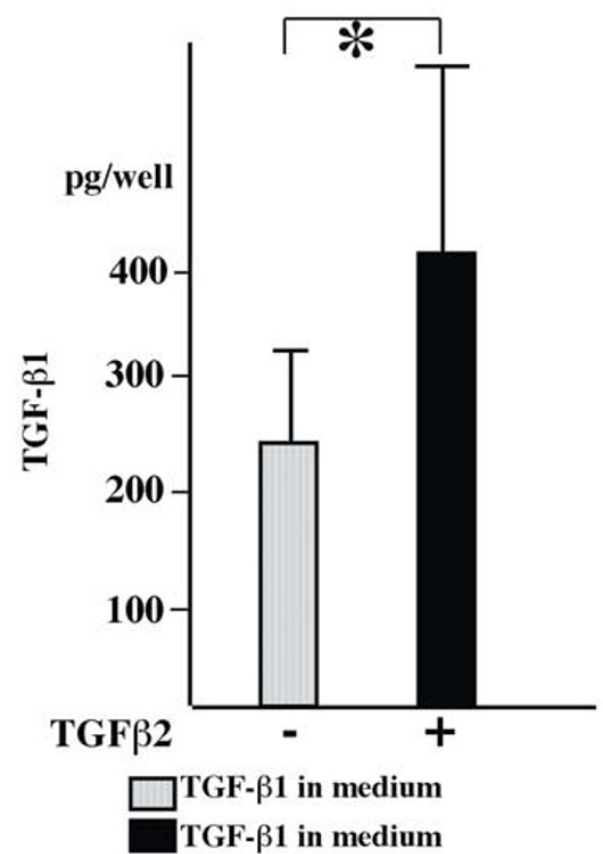

b
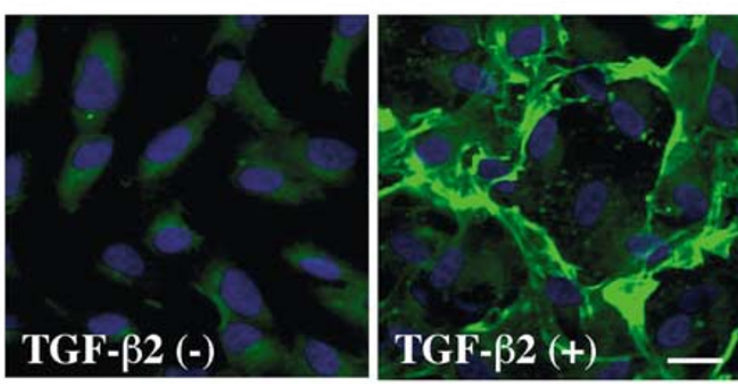

C

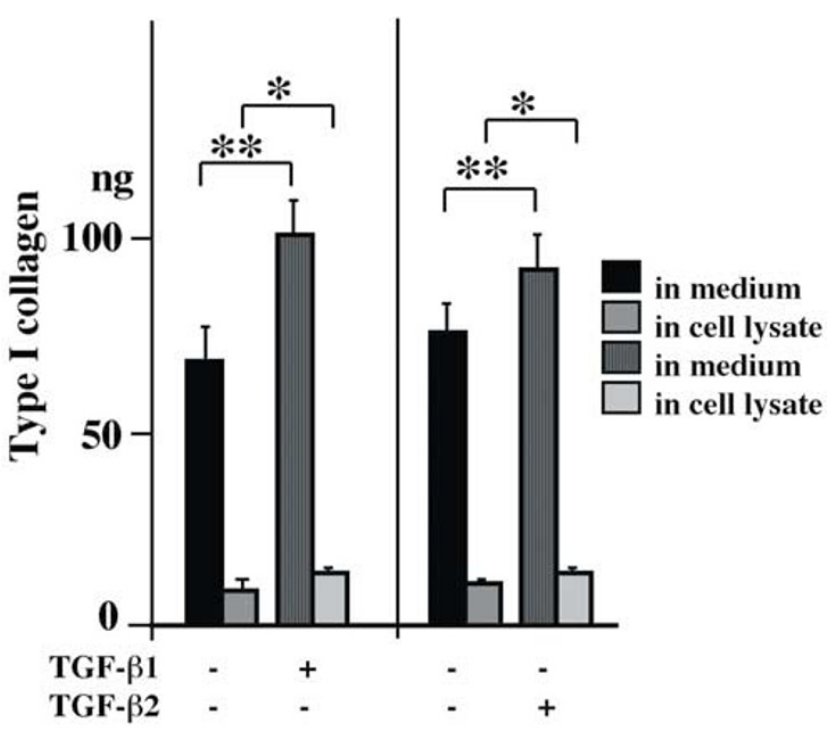

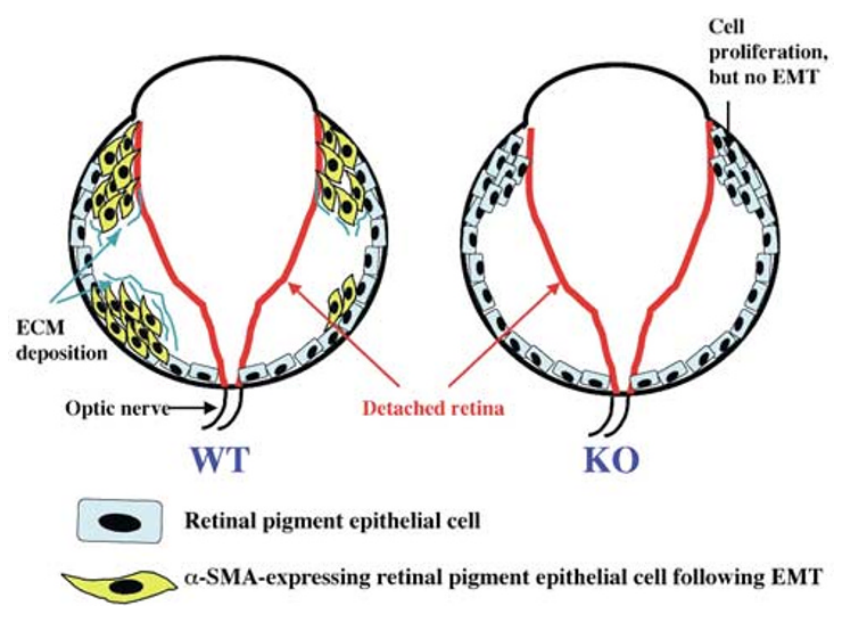

Figure 9 Model of development of following retinal detachment in the mouse eye. Following retinal detachment in a Smad3 $3^{+1+}$ (WT) eye, RPE cells undergo EMT and form multilayers of $\alpha$ SMApositive mesenchymal-like cells, which express extracellular matrix under the detached retina. Similar changes are not seen in RPE cells in Smad3 ${ }^{\text {ex8/ex8 }}(\mathrm{KO})$ eyes, demonstrating a dependence of these processes on the Smad3 pathway. Cell proliferation was seen in peripheral areas of the subretinal space in both WT and $\mathrm{KO}$ eyes, but, like cells in the posterior zone, these cells do not express EMT in KO eyes.

pressive effects of TGF- $\beta$ on ARPE-19 (Figure 9c). These data strengthen the argument that antagonists of Smad3 might be able to block the fibrogenic traction detachment of the retina not only at the level of TGF- $\beta$-mediated mesenchymal transition of RPE cells but also by blocking of expression of another key mediator of the disease process, PDGF.

In summary, we have shown that the hallmarks PVR-production of $\alpha$ SMA and pathogenic accumulation of extracellular matrix proteins that ultimately contribute to traction detachment of the retina-are completely blocked in mice lacking Smad3. This is a most important observation identifying for the first time a specific signaling pathway that might be an important new target for design of therapeutics against PVR and suggesting that interfering with Smad3 signaling may have clinical application in treatment of this devastating disease that can lead to blindness.

Figure 8 TGF- $\beta 2$ enhances expression of TGF- $\beta 1$ and type I collagen in ARPE-19 cells. (a) An enzyme-immunoassay as described in Materials and methods shows an increment of amount of TGF- $\beta 1$ in medium of ARPE-19 cells treated with exogenous TGF- $\beta 2$. (b) Immunofluorescent staining shows increased cytoplasmic fluorescence and pericellular deposition of type I collagen in TGF- $\beta 2$-treated cultures as compared with the control. (c) Both TGF- $\beta 1$ and, to a somewhat lesser extent, TGF- $\beta 2$ increase the amount of type I collagen in both culture medium and cell lysate as determined by using an enzyme-linked immunosorbent assay as described in Materials and methods. Immunofluorescence staining with DAPI nuclear staining (b): bar, $20 \mu \mathrm{m}$. 


\section{Acknowledgements}

This study was supported by a grant from the Ministry of Education, Science, Sports and Culture of Japan (No. 15591871) and Uehara Memorial Foundation (both to SS) and a research grant on Priority Areas from Wakayama Medical University (to AOYM, and SS).

\section{References}

1 Pastor JC, de la Rua ER, Martin F. Proliferative vitreoretinopathy: risk factors and pathobiology. Prog Retin Eye Res 2002;21:127-144.

2 Casaroli-Marano RP, Pagan R, Vilaro S. Epithelialmesenchymal transition in proliferative vitreoretinopathy: intermediate filament protein expression in retinal pigment epithelial cells. Invest Ophthalmol Vis Sci 1999;40:2062-2072.

3 Sheridan CM, Occleston NL, Hiscott P, et al. Matrix metalloproteinases: a role in the contraction of vitreoretinal scar tissue. Am J Pathol 2001;159:1555-1566.

4 Grisanti S, Guidry C. Transdifferentiation of retinal pigment epithelial cells from epithelial to mesenchymal phenotype. Invest Ophthalmol Vis Sci 1995;36: 391-405.

5 Lee SC, Kwon OW, Seong GJ, et al. Epitheliomesenchymal transdifferentiation of cultured RPE cells. Ophthalmic Res 2001;33:80-86.

6 Cassidy L, Barry P, Shaw C, et al. Platelet derived growth factor and fibroblast growth factor basic levels in the vitreous of patients with vitreoretinal disorders. Br J Ophthalmol 1998;82:181-185.

7 Hinton DR, He S, Jin ML, et al. Novel growth factors involved in the pathogenesis of proliferative vitreoretinopathy. Eye 2002;16:422-428.

8 Kon CH, Occleston NL, Aylward GW, et al. Expression of vitreous cytokines in proliferative vitreoretinopathy: a prospective study. Invest Ophthalmol Vis Sci 1999;40:705-712.

9 Liang X, Li C, Li Y, et al. Platelet-derived growth factor and basic fibroblast growth factor immunolocalized in proliferative retinal diseases. Chin Med J 2000;113: 144-147.

10 Yamamoto T, Takeuchi S, Suzuki K, et al. Expression and possible roles of activin $A$ in proliferative vitreoretinal diseases. Jpn J Ophthalmol 2000;44: 221-226.

11 Bochaton-Piallat ML, Kapetanios AD, Donati G, et al. TGF- $\beta 1$, TGF- $\beta$ receptor II and ED-A fibronectin expression in myofibroblast of vitreoretinopathy. Invest Ophthalmol Vis Sci 2000;41:2336-2342.

12 Connor Jr TB, Roberts AB, Sporn MB, et al. Correlation of fibrosis and transforming growth factor-beta type 2 levels in the eye. J Clin Invest 1989;83:1661-1666.

13 Bhowmick NA, Ghiassi M, Bakin A, et al. Transforming growth factor-b1 mediates epithelial to mesenchymal transdifferentiation through a RhoA-dependent mechanism. Mol Biol Cell 2001;12:27-36.

14 Nicolas FJ, Lehmann K, Warne PH, et al. Epithelial to mesenchymal transition in Madin-Darby canine kidney cells is accompanied by down-regulation of Smad3 expression, leading to resistance to transforming growth factor-beta-induced growth arrest. J Biol Chem 2003;278:3251-3256.
15 Janda E, Lehmann K, Killisch I, et al. Ras and TGF- $\beta$ cooperatively regulate epithelial cell plasticity and metastasis: dissection of Ras signaling pathways. J Cell Biol 2002;156:299-314.

16 Oft M, Akhurst RJ, Balmain A. Metastasis is driven by sequential elevation of H-ras and Smad2 levels. Nat Cell Biol 2002;4:487-494.

17 Pfeffer BA, Flanders KC, Guerin CJ, et al. Transforming growth factor $\beta 2$ is the predominant isoform in the neural retina, retinal pigment epithelium-choroid and vitreous of the monkey eye. Exp Eye Res 1994;59:323-333.

18 Kurosaka D, Muraki $\mathrm{Y}$, Inoue $\mathrm{M}$, et al. TGF- $\beta 2$ increases alpha-smooth muscle actin expression in bovine retinal pigment epithelial cells. Curr Eye Res 1996;15:1144-1147.

19 Stocks SZ, Taylor SM, Shiels IA. Transforming growth factor- $\beta 1$ induces a-smooth muscle actin expression and fibronectin synthesis in cultured human retinal pigment epithelial cells. Clin Experiment Ophthalmol 2001;29:33-37.

20 Battegay EJ, Raines EW, Seifert RA, et al. TGF- $\beta$ induces bimodal proliferation of connective tissue cells via complex control of an autocrine PDGF loop. Cell 1990;63:515-524.

21 Bronzert DA, Bates SE, Sheridan JP, et al. Transforming growth factor- $\beta$ induces platelet-derived growth factor (PDGF) messenger RNA and PDGF secretion while inhibiting growth in normal human mammary epithelial cells. Mol Endocrinol 1990;4:981-989.

22 Choudhury P, Chen W, Hunt RC. Production of platelet-derived growth factor by interleukin-1 $\beta$ and transforming growth factor- $\beta$-stimulated retinal pigment epithelial cells leads to contraction of collagen gels. Invest Ophthalmol Vis Sci 1997;38:824-833.

23 Leask A, Holmes A, Black CM, et al. CTGF gene regulation: requirements for its induction by TGF $\beta 2$ in fibroblasts. J Biol Chem 2003;278:13008-13015.

24 Piek E, Roberts AB. Suppressor and oncogenic roles of transforming growth factor-beta and its signaling pathways in tumorigenesis. Adv Cancer Res 2001;83: $1-54$.

25 Shi Y, Massague J. Mechanisms of TGF- $\beta$ signaling from cell membrane to the nucleus. Cell 2003;113:685-700.

26 ten Dijke P, Goumans MJ, Itoh F, et al. Regulation of cell proliferation by Smad proteins. J Cell Physiol 2002;191:1-16.

27 Bakin AV, Tomlinson AK, Bhowmick NA, et al. Phosphatidylinositol 3-kinase function is required for transforming growth factor $\beta$-mediated epithelial to mesenchymal transition and cell migration. J Biol Chem 2000;275:36803-36810.

28 Oft M, Peli J, Rudaz C, et al. TGF- $\beta 1$ and Ha-Ras collaborate in modulating the phenotypic plasticity and invasiveness of epithelial tumor cells. Genes Dev 1996;10:2462-2477.

29 Itoh S, Thorikay M, Kowanetz M, et al. Elucidation of Smad requirement in transforming growth factor- $\beta$ type I receptor-induced responses. J Biol Chem 2003;278:3751-3761.

$30 \mathrm{Yu}$ L, Hebert MC, Zhang YE. TGF- $\beta$ receptor-activated p38 MAP kinase mediates Smad-independent TGFbeta responses. EMBO J 2002;21:3749-3759.

31 Yang X, Letterio JJ, Lechleider RJ, et al. Targeted disruption of SMAD3 results in impaired mucosal immunity and diminished $\mathrm{T}$ cell responsiveness to TGF- $\beta$. EMBO J 1999;18:1280-1291. 
32 Saika S, Kono-Saika S, Tanaka S, et al. Smad3 signaling is required for epithelial-mesenchymal transition of lens epithelium after injury. Am J Pathol 2003;164:651-663.

33 Sato M, Muragaki Y, Saika S, et al. Targeted disruption of TGF- $\beta /$ Smad3 signaling protects against renal tubulointerstitial fibrosis induced by unilateral ureteral obstruction. J Clin Invest 2003;112:1486-1494.

34 Dunn KC, Aotaki-Keen AE, Putkey FR, et al. ARPE-19, a human retinal pigment epithelial cell line with differentiated properties. Exp Eye Res 1996;62: 155-169.

35 Martini B, Pandey R, Ogden TE. Cultures of human retinal pigment epithelium. Modulation of extracellular matrix. Invest Ophthalmol Vis Sci 1992;33: $516-521$.

36 Saika S, Shiraishi A, Liu CY, et al. Role of lumican in the corneal epithelium during wound healing. J Biol Chem 2000;275:2607-2612.

37 Saika S, Saika S, Liu CY, et al. TGF $\beta 2$ in corneal morphogenesis during mouse embryonic development. Dev Biol 2001;240:419-432.

38 Saika S, Ooshima A, Hashizume N, et al. Effect of lysyl hydroxylase inhibitor, minoxidil, on ultrastructure and behavior of cultured rabbit subconjunctival fibroblasts. Graefes Arch Clin Exp Ophthalmol 1995;233:347-353.

39 Ohno-Matsui K, Hirose A, Yamamoto S, et al. Inducible expression of vascular endothelial growth factor in adult mice causes severe proliferative retinopathy and retinal detachment. Am J Pathol 2002;160:711-719.

40 Seo MS, Okamoto N, Vinores MA, et al. Photoreceptorspecific expression of platelet-derived growth factor-B results in traction retinal detachment. Am J Pathol 2000;157:995-1005.

41 Yeo JH, Sadeghi J, Campochiaro PA, et al. Intravitreous fibronectin and platelet-derived growth factor. New model for traction retinal detachment. Arch Ophthalmol 1986;104:417-421.

42 Hisatomi T, Sakamoto T, Murata T, et al. Relocalization of apoptosis-inducing factor in photoreceptor apoptosis induced by retinal detachment in vivo. Am J Pathol 2001;158:1271-1278.

43 Oshima Y, Sakamoto T, Hisatomi T, et al. Gene transfer of soluble TGF- $\beta$ type II receptor inhibits experimental proliferative vitreoretinopathy. Gene Therapy 2002;9: 1214-1220.

44 Ikuno Y, Kazlauskas A. An in vivo gene therapy approach for experimental proliferative vitreoretino- pathy using the truncated platelet-derived growth factor alpha receptor. Invest Ophthalmol Vis Sci 2002;43:2406-2411.

45 Valeria Canto SM, Gallo JE, Dodds RA, et al. A mouse model of proliferative vitreoretinopathy induced by dispase. Exp Eye Res 2002;75:491-504.

46 Anderson DH, Guerin CJ, Erickson PA, et al. Morphological recovery in the reattached retina. Invest Ophthalmol Vis Sci 1986;27:168-183.

47 Ando A, Ueda M, Uyama M, et al. Enhancement of dedifferentiation and myoid differentiation of retinal pigment epithelial cells by platelet derived growth factor. Br J Ophthalmol 2000;84:1306-1311.

48 Saika S, Miyamoto T, Tanaka S, et al. Response of lens epithelial cells to injury: role of lumican in epithelialmesenchymal transition. Invest Ophthalmol Vis Sci 2003;44:2094-2102.

49 Knupp C, Amin SZ, Munro PM, et al. Collagen VI assemblies in age-related macular degeneration. J Struct Biol 2002;139:181-189.

50 Saika S, Miyamoto T, Ishida I, et al. TGF $\beta$-Smad signalling in postoperative human lens epithelial cells. Br J Ophthalmol 2002;86:1428-1433.

51 Somasundaram R, Schuppan D. Type I, II, III, IV, V, and VI collagens serve as extracellular ligands for the isoforms of platelet-derived growth factor (AA, BB, and AB). J Biol Chem 1996;271:26884-26891.

52 Jaffe GJ, Harrison CE, Lui GM, et al. Activin expression by cultured human retinal pigment epithelial cells. Invest Ophthalmol Vis Sci 1994;35:2924-2931.

53 Roberts AB, Sporn MB. The transforming growth factors- $\beta$. In: Sporn MB, Roberts AB (eds). Handbook of Experimental Pharmacology. Peptide Growth Factors and Their Receptors. Springer-Verlag: New York, 1990, pp 419-472.

54 Carrington L, McLeod D, Boulton M. IL-10 and antibodies to TGF- $\beta 2$ and PDGF inhibit RPE-mediated retinal contraction. Invest Ophthalmol Vis Sci 2000; 41:1210-1216.

55 Sintich SM, Lamm ML, Sensibar JA, et al. Transforming growth factor-b1-induced proliferation of the prostate cancer cell line, TSU-Pr1: the role of plateletderived growth factor. Endocrinology 1999;140: 3411-3415.

56 Taylor LM, Khachigian LM. Induction of plateletderived growth factor B-chain expression by transforming growth factor- $\beta$ involves transactivation by Smads. J Biol Chem 2000;275:16709-16716. 